\title{
Implikasi Tata Kelola Produksi terhadap Kualitas pada Gerabah Desa Pagelaran Kabupaten Malang Jawa Timur
}

\author{
Muhammad 'Afaf Hasyimy', Robby Hidajat² \\ ${ }^{1}$ Mahasiswa Program Studi Keguruan Seni Rupa, Jurusan Seni dan Desain, Fakultas Sastra, Universitas Neg- \\ eri Malang, Jl Semarang no. 5 Kota Malang, Kode Pos 65145, Jawa Timur Indonesia \\ ${ }^{2}$ Staf Pengajar Jurusan Seni dan Desain, Fakultas Sastra, Universitas Negeri Malang, \\ Jl Semarang no. 5 Kota Malang, Kode Pos 65145, Jawa Timur Indonesia \\ ${ }^{1}$ m.afafhasyimy.1902518@students.um.ac.id, ${ }^{2}$ robby.hidajat.fs@um.ac.id
}

Artikel ini bertujuan mengkaji implikasi tata kelola produksi gerabah di Desa Pagelaran di Malang Jawa Timur. Tata kelola yang dimaksud adalah konsep, sistem, dan hasil produksi gerabah yang dilakukan oleh perajin di Desa Pagelaran. Mengkaji tata kelola tersebut, sebab adanya kecenderungan produksi gerabah semakin terdesak oleh benda-benda buatan pabrik. Hal ini secara perlahan dirasakan oleh para perajin sebagai ancaman. Pada tahun 2020, perajin gerabah di Desa Pagelaran mulai mengawali meningkatkan kualitas produk, yaitu dengan adanya paguyuban yang dipimpin oleh Yatmono (57 th). Upaya paguyuban masih mengalami hambatan, karena kebiasaan konvensional perajin, yaitu menggantungkan pada tengkulak. Sehingga upaya inovasi seringkali mengalami hambatan. Metode penelitian menggunakan deskriptif kualitatif yang difokuskan pada tata kelola produksi gerabah. Data menggunakan metode wawancara, observasi dan kajian dokumen. Teknik keabsahan data menggunakan triangulasi data (sumber) melalui wawancara narasumber kunci, dan analisis data menggunakan teori fungsi dan tata kelola produksi. Hasil kajian menunjukan ada kecenderungan yang dapat diperhatikan dari aspek, (1) tata kelola konvensional dan progresif, (2) perlakukan kualitas untuk produksi bersifat kualitas dan kuantitas, dan (3) tata kelola gerabah yang berdampak ekonomi. Upaya menciptakan produk yang mempunyai dampak perluasan bisnis, sehingga penghargaan terhadap produk gerabah tidak lagi dihitung sebagai kuantitas, tapi barang selalu diposisikan dalam ukuran kualitas.

Kata kunci : tata kelola produksi, gerabah, kualitas produk

\section{The Implications of Production Governance towards the Quality of Pottery in Pagelaran Village, Malang Regency, East Java}

This article was focused on examining the implications governance of pottery production in Pagelaran Village in Malang, East Java. The governance purposed was the concept, system, and product of pottery production carried out by craftsmen in Pagelaran Village. The reviewing the governance was due to the tendency of pottery production which pushed by factory-made objects. This situation was slowly felt as a threat by the craftsmen. In 2020, pottery craftsmen in Pagelaran Village started to improve the quality of their products by conducting an association led by Yatmono ( $57 \mathrm{y} . \mathrm{o})$. The assosiation still faces some obstacles, due to the conventional habit of craftsmen who always depend on the middlemen. So that innovation efforts often experience obstacles. The research method used was descriptive qualitative which focused on governance of pottery production. The data gathered from interview, observation and document review methods. The data validity technique used in this study was triangulation of data (sources) through key informant interviews, and data analysis used the function theory and production management. The results of the study show that there were trends that can be considered from the aspects, (1) conventional and progressive governance, (2) quality treatment for quality and quantity production, and (3) pottery governance that have economic impact. The Efforts to create products which have an impact to the business expansion, so that the appreciation for the pottery products is no longer counted as quantity, but goods which are always positioned in terms of quality.

Keywords : the governance of production, pottery, product quality 


\section{PENDAHULUAN}

Pada tahun 1950-an, Setiap Desa di pulau Jawa tumbuh dan berkembang sentra produksi gerabah tradisional (Pratiwi, 2019). Keberadaan sentra produksi gerabah tersebut merupakan penyangga kebutuhan rumah tangga, alat kerja dari para pengusaha warung makanan, dan berbagai bentuk peralatan ritual tradisional, baik untuk menyimpan air, bunga, atau tempat pembakaran kemenyan (I Wayan Mudra, 2019).

Produk gerabah yang dihasilkan pada setiap sentra produk gerabah di Jawa pada umumnya dikerjakan dengan mengolah tanah liat, membentuk, dan membakar untuk mengeraskan, sehingga menjadi benda pakai rumah tangga dan kegiatan ritual tradisional (Betaubun et al., 2019). Pekerjaan dilakukan dengan teknik yang sederhana, yaitu dengan cara melumatkan tanah liat, membentuk dengan teknik pilin, atau dibentuk dengan Teknik pinching yang dibentuk dengan tangan secara langsung. Bendabenda gerabah yang diproduksi dikerjakan dengan cara manual, dilakukan dengan menggunakan tangan melalui alat pemutar dari kayu (Akbar \& Prastawa, 2019). Alat putar pembuatan gerabah yang digunakan perajin di Desa Pegelaran adalah alat putar datar dan alat putar miring. Produksi gerabah dengan menggunakan alat putar miring umumnya bentuk gerabah jenis ukuran kecil, sedangkan bentuk gerabah ukuran besar menggunakan alat putar datar.

Gambar no. 1 dan 2 menunjukan perbedaan alat teknik putar miring dan datar. Alat putar miring menghasilkan difungsikan dalam membentuk gerabah berukuran tinggi kurang lebih $20 \mathrm{~cm}$, sedangkan untuk alat putar datar bisa menghasilkan gerabah berukuran $100 \mathrm{~cm}$.

Desa Pagelaran di Kabupaten Malang Jawa Timur merupakan salah satu sentra produksi gerabah tradisional (Iriaji, 2017). Sifat kultural itu ditentukan oleh tata letak lokasi produksi, bersifat fungsional, dan memiliki sistem kerja yang khas, yaitu dilakukan di dalam rumah yang dikerjakan oleh anggota keluarga. Keberadaan sentra gerabah di Desa Pagelaran ini sudah ada sejak tahun 1930an, produknya mensuplai kebutuhan masyarakat di daerah Malang bagian timur (Yatmono, wawancara tanggal 2 Desember 2020). Selain itu sentra industri gerabah Pagelaran sebagai sarana belajar, umumnya sekolah yang lokasinya tidak jauh dengan sentra industri gerabah Pagelaran. Hal ini disadari oleh guru bahwa kegiatan belajar dengan mengunjungi secara langsung dapat memiliki potensi untuk ditransformasikan pada siswa sekolah, karena emosi siswa terhadap apa yang dilihat langsung dapat memotivasi siswa dan mudah menangkap, sebab siswa memaksimalkan indera yang dimiliki (Mujiyono et al., 2021). Peneliti telah melakukan penelitian yang terkait dengan pembelajaran yang dilakukan sentra industri gerabah Pagelaran, hasilnya menunjukan bahwa

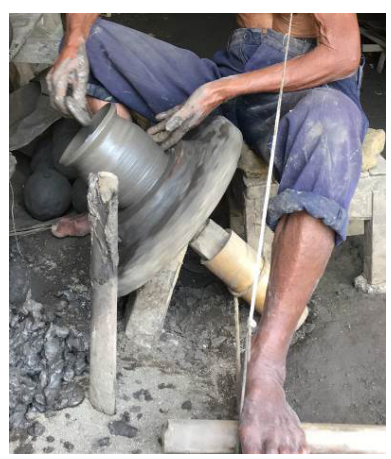

Gambar 1. Alat putar miring

(Sumber: Foto Afaf, 2020)

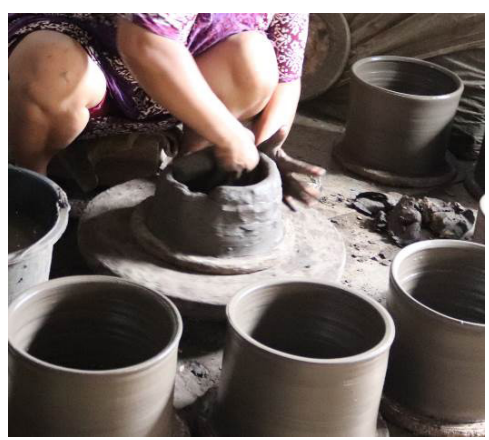

Gambar 2. Alat putar datar

(Sumber: Foto Afaf, 2020)

pembelajaran memberikan dampak siswa lebih antusias dalam belajar, utamanya dalam mempelajari kearifan lokal. Hal ini semata-mata untuk memberikan penguatan terhadap esksitensi kearifan lokal yang khas di Malang Jawa Timur (M. 'Afaf Hasyimy, 2020). Selain itu dapat menumbuhkan kesadaran masyarakat dalam melestarikan budaya lokal (Darma Oka et al., 2021).

Berbagai penelitian terdahulu yang dilakukan di sentra industri gerabah Pagelaran. Seperti penelitian yang dilakukan oleh (Iriaji, 2019a) pada desertasinya, penelitiannya mengkaji pada permasalahan adaptasi dan sistem penularan gerabah. Berbeda pula dengan penelitian yang dilakukan oleh (Pratiwi et al., 2019), penelitiannya mengkaji terkait produk-produk yang dihasilkan oleh perajin, kedua penelitian tersebut belum mengarah pada implikasi tata kelola terhadap kualitas produksi gerabah, sehingga terdapat perbedaan pada penelitian yang dilakukan peneliti dengan peneliti sebelumnya.

Produksi gerabah di Desa Pagelaran, dari waktu ke waktu mengalami perubahan sosial, utamanya sistem regenerasi perajin. Pada saat ini, perajin yang masih bertahan berusia kurang lebih 40-60 tahun dan jumlah perajin sebanyak 163 perajin yang masih bertahan memproduksi gerabah, berbeda pada tahun 1960-an jumlah perajin waktu itu kurang lebih sebanyak 275 keluarga dan pada saat itu gerabah Pagelaran dikenal sebagai Desa penghasil peralatan dapur tradisional di Malang (Iriaji, 2019b). Sementara perajin muda tidak tumbuh secara signifikan 
dengan jumlah perajin senior. Hal ini perajin muda dipengaruhi oleh arus budaya global yang masuk (Brata \& Sudirga, 2019), utamanya di Desa Pagelaran. Sutrisno mengatakan perajin muda lebih memilih cara yang lebih praktis, dan mereka pada umumnya mengetahui kebutuhan pasar. Sementara para perajin senior pada umumnya menggantungkan para tengkulak yang datang (Sutrisno, wawancara tanggal 15 November 2020). Adanya kesenjangan antara inovasi, dan desakan ekonomi sesaat para perajin. Maka hal tersebut mendorong peneliti untuk mengkaji tata kelola produk gerabah dan keterkaitan pada peningkatan kualitas produk gerabah, sehingga penelitian ini dapat memberikan informasi pada perajin dan pemerintah desa untuk memahami tata Kelola produksi yang memiliki dampak ekonomi. Fokus peneliti diarahkan pada sistem kerja dan hasil kerja yang memiliki dampak ekonomi bagi para perajinnya. Peneliti merujuk pada tata kelola yang dikembangkan dalam aktivitas kesenian, yang terkait dengan pengolahan bahan, proses, dan hasil produksi (Prakoso, 2020).

\section{METODE PENELITIAN}

Metode menggunakan deskriptif kualitatif yang difokuskan pada tata kelola produksi gerabah. Pengumpulan data dilakukan dengan metode wawancara, observasi dan kajian dokumen. Untuk menentukan kredibilitas data dilakukan triangulasi (Moleong, 2002) sumber melalui wawancara narasumber kunci, Sutrisno (53 th) seorang perajin tradisional yang responsif terhadap progresivitas produksi sebagai produk komersial, Sukirno (57 th) mewakili karakteritik pengelolaan produksi gerabah secara tradisional, dan Yatmono (57 th) ketua paguyuban perajin gerabah Pagelaran. Analisis data menggunakan teori fungsi. Penelusuran data awal menggunakan rujukan narasumber kunci Sutrisno (53 th), pengalamannya sebagai perajin diwarisi dari orang tuanya, Sukirno (57 th) adalah perajin gerabah untuk perlengkapan ritual kejawen, dan Yatmono (57 th) sebagai ketua paguyuban perajin gerabah di Desa Pagelaran. Observasi mempertimbangkan pola interaksi sosial, hubungan kekerabatan, dan sistem pembagian kerja. Siklus kerja tradisional masih tampak membekas, sungguhpun ada usaha untuk meninggalkan. Pengamatan dan fokus pada potensial kinerja perajin menjadi fokus pengamatan utama. Analisis data menggunakan interpertasi serta memperhatikan gejala yang memiliki makna signifikan terhadap tata kelola produksi gerabah dan kaitannya dengan dampak kinerja perajin terhadap upaya inovasi yang telah dilakukan.

\section{ANALISIS DAN INTERPRETASI DATA}

\section{Paparan Data}

Produksi gerabah di Desa Pagelaran Kabupaten Malang Jawa Timur telah mengalami kondisi yang sangat berbeda dengan masa sebelum kemerdekaan. Sentra produksi gerabah yang sudah mensuplai kebutuhan rumah tangga

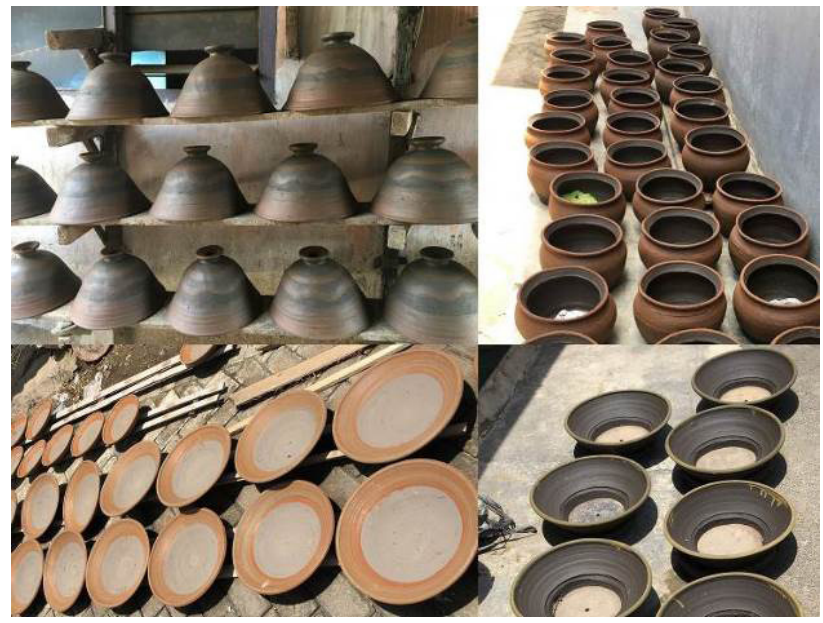

Gambar 3. Produk gerabah tradisional Desa Pagelaran (Sumber: Foto Afaf, 2020)

sejak tahun 1930-an terus mengalami perkembangan hingga tahun 1970-an. Perkembangan yang dimaksud adalah permintaan kebutuhan pasar terhadap produk gerabah rumah tangga, seperti cobek, kendi, tempayan, tungku api, atau prapen (tungku pembakaran kemenyan).

Gambar no. 3 menunjukan berbagai bentuk gerabah poduksi di Desa Pagelaran. Sentra ini menyangga 4 pasar tradisional di Malang, yaitu di bagian barat yakni pasar Kepanjen, di bagian utara terdapat pasar Gondanglegi, sementara di bagian timur terdapat pasar Turen, sedangkan di bagian selatan terdapat pasar Bantur (Mariono \& Puji, 2016). Jika memperhatikan posisi Desa Pagelaran, maka sentra gerabah tradisional ini memiliki posisi yang strategis, berada di tengah-tengah yang dapat dijangkau dengan kendaraan umum. Posisi ini ternyata menguntungkan para tengkulak, hal ini diungkapkan pada penelitian disertasi (Iriaji, 2019) bahwa harga penjualan gerabah merupakan kekuasaan dan wewenang tengkulak, sebab perajin membutuhkan modal memproduksi gerabah. Sementara perajin tidak banyak mendapatkan peningkatan penghasilan. Hal ini diungkapkan oleh Sutrisno bahwa pendapatan penghasilan dari menjual gerabah, perajin tidak mendapatkan keuntungan yang banyak, perajin mengutamakan untuk memperoleh uang modal memproduksi gerabah. Sungguhpun keberadaan sentra produksi gerabah di Desa Pagelaran ini telah tumbuh di awal abad XX, Menurut ayah Sutrisno, sentra gerabah Pagelaran sudah tumbuh sejak tahun 1930an. Hal itu benar-benar menjadi pusat produksi gerabah tradisional di Malang (Ponimin et al., 2019). Namun mulai tahun 1970-an, produksi gerabah di Desa Pagelaran mulai terasa penurunan, banyak mendapatkan saingan yang ketat dengan produk gerabah dari Yogyakarta dan Bali, namun di tingkat pasar lokal, produk gerabah dari Desa Pagelaran masih diminati, seperti yang dilakukan oleh keluarga Sukirno, pada saat ini masih tetap dapat memproduksi gerabah tradisional di berbagai pasar di Malang (Koniherawati \& Harjani, 2019). Sungguhpun 


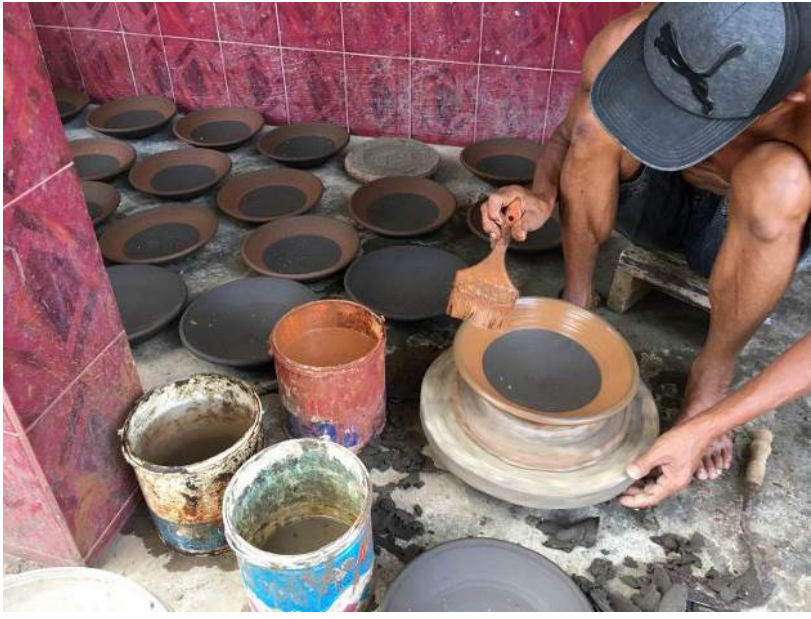

Gambar 4. Kondisi kerja perajin tradisional di Desa Pagelaran (Sumber: Foto Afaf, 2020)

benar-benar tergantung dengan para tengkulak. Kadang produksi gerabah tertentu yang telah selesai, tidak dapat dijual. Karena pasar tidak menghendaki produk yang telah dikerjakan. Sehingga Sukirno harus menerima uang muka terlebih dahulu untuk produk yang dipesan tengkulak.

Hingga tahun 1980-an, produksi gerabah di Desa Pagelaran masih dikelola secara tradisional. Yakni pengelolaan produksi gerabah didasarkan atas cara kerja; penyiapan bahan, proses, dan hasil kerja (M. A. Hasyimy, 2020). Mereka mengerjakan gerabah di dalam rumah dan dikerjakan dengan keluarga, mereka saling membantu proses produksi mulai dari mengolah hingga membakar. Pada tahun 2000-an, perajin di Desa Pagelaran mulai dibentuk paguyuban yang menyatukan antara perajin yang satu dengan perajin yang lain, kondisi ini terjadi karena pola hubungan sosial antar perajin mulai kurang harmonis, hal tersebut mempengaruhi persaingan harga barang (Yatmono, wawancara 2 Desember 2020). Mengingat semenjak tahun 1970-an sistem penjualan produk selalu dilakukan berdasarkan pesanan tengkulak dari luar daerah, mereka datang antara 2-3 bulan sekali untuk mengambil gerabah. Tetapi pada tahun-tahun berikutnya, mulai tumbuh tengkulak yang berasal dari dalam desa mereka sendiri. Hal itu yang menyebabkan sistem harga barang menjadi kurang menguntungkan bagi perajin (Iriaji, 2019).

Peneliti bertolak dari kondisi yang demikian ini, sehingga mengobservasi tata kelola produksi gerabah yang dilakukan oleh perajin di Desa Pagelaran. Hasil observasi menunjukan bahwa para perajin gerabah memiliki pola hidup sebagai masyarakat agraris, mereka kebanyakan bekerja secara individu dalam kelompok keluarga (Ponimin et al., 2019).

Gambar no. 4 gambar ini menunjukan, sebuah keluarga perajin yang lain. Sutrisno, yang bekerja hanya seorang diri. Hasilnya tentu tidak dapat diharapkan. Secara finansial memang ada perbedaan, lebih tinggi harga produk yang dihasilkan oleh Sutrisno, namun secara produktivitas masih bisa dijangkau oleh para perajin tradisional yang dibantu oleh keluarganya. Bahkan pembakarannya kadang dapat dilakukan bersama-sama dengan tetangga yang produknya hampir sama. Sementara untuk Sutrisno harus membakar secara khusus.

Hanya ketika pembelian tanah liat sebagai bahan baku, seringkali mereka membicarakan dengan perajin yang terdekat, utamanya yang memiliki hubungan kekerabatan. Karena jika mereka membeli tanah liat dalam jumlah sedikit harganya akan terpaut pada transportasi. Namun selebihnya mereka bekerja secara individu di dalam rumah masing-masing. Bahkan sistem menjual produk juga demikian. Seringkali mereka mendapatkan uang muka untuk memesan sejumlah produk tertentu. Sistem ini sebenarnya memiliki kelemahan, karena akan banyak menguntungkan para tengkulak, Sutrisno, salah satu perajin yang berpengalaman seringkali mendiskusikan hal tersebut dengan ketua paguyuban. Namun hingga saat ini, perajin di Desa Pagelaran masih belum dapat dikondisikan menyadari keberadaan para tengkulak. Mereka hanya mendorong untuk mengadakan benda-benda yang diminati oleh pasaran lokal yang harganya sangat rendah. Karena kebutuhan pasar lokal ditentukan oleh musim, permintaan cobek (piring gerabah) akan meningkat jika mendekati bulan maulid (hari kelahiran Nabi Muhammad SAW). Umumnya di daerah Malang bagian selatan masih terdapat tradisi guak ajang, yakni memecahkan cobek di depan rumah (setelah isi makanan dan buah-buahan dipindahkan dari cobek tersebut), masyarakat mempercayai guak ajang sebagai simbol menghilangkan bala, menghilangkan hal buruk yang ada di rumah (Iriaji et al., 2020). Sementara antara bulan Agustus permintaan pot bunga meningkat, karena pemerintah daerah setiap bulan agustus mengadakan lomba menghias lingkungan dengan bunga hias di setiap kampung masing-masing. Ketergantungan terhadap musim tersebut, para perajin tidak mampu menentukan jenis produk yang dihasilkan, sehingga produk gerabah tertentu yang dapat mereka hasilkan, seperti prapen dan berbagai jenis gerabah lainnya digunakan oleh umat Hindu dan Budha sebagai perlengkapan ibadah (Gunada, 2021). Hal ini disadari oleh Surtisno.

Sutrisno menyadari berdasarkan pengalaman produk gerabah yang dipelajari dari sentra yang lain, setidaknya dari sentra keramik souvenir di Dinoyo Malang. Secara teknis memang tidak dapat disamakan, namun Sutrisno sudah tidak lagi membuat produk gerabah tradisional. Ada diversifikasi yang berusaha untuk dilakukan inovasi, sama-sama membuat pot bunga, atau belanga untuk menanak nasi. Namun Sutrisno mencoba untuk berinovasi, setidaknya membuat yang lebih halus, pembakaran yang lebih eksklusif, yaitu dengan membuat hasil bakaran lebih hitam, atau lebih coklat terakotanya muncul, bahkan proses pembakaran yang dilakukan dua kali proses pembakaran, untuk mendapatkan warna gerabah yang estetik. Hal ini 
sebagai upaya dalam meningkatkan peminat gerabah yang makin menurun, seperti yang dikemukakan pada hasil penelitian (Prabowo \& Rindawati, 2019) bahwa pada saat ini menurunnya peminat gerabah tradisional. Sehingga yang dilakukan oleh Sutrisno ini sebagai awal dalam meningkatkan kembali peminat gerabah. Sutrisno memang belum banyak diikuti, oleh perajin yang lain. Namun langkah-langkah tata kelola produksi sudah mulai memberikan inspirasi pada perajin di Desa Pagelaran. Hal ini dikarenakan sikap Sutrisno yang terbuka, dan tidak segan-segan memberikan pengetahuannya ke perajin yang lain. Hanya saja, beberapa perajin yang masih merasa diuntungkan dengan pola lama, yaitu ada pinjaman modal awal yang diberikan sejumlah tengkulak, umumnya memberi pinjaman modal sekitar 50\% dari harga gerabah yang dibeli, bahkan beberapa tengkulak memberi uang lunas diawal. Sehingga yang dilakukan adalah menjalankan pekerjaan pesanan, dan tidak lagi memikirkan dan banyak pertimbangan. Karena para tengkulak hanya melayani pasar umum yang semakin langkah.

Berberapa upaya yang telah dilakukan Sutrisno, secara perlahan telah mengawali dalam meningkatkan kualitas produk yaitu dengan membenahi kualitas produk, artinya membuat barang lebih meningkat kualitasnya. Hal ini tentunya akan kembali menentukan dan memilih kualitas tanah liat, mempertimbangkan kadar air, serta mengerjakan pelumatan lebih lama, sehingga elasitas yang tinggi. Kondisi tersebut ternyata juga masing mengalami hambatan, karena kebiasaan konvensional yang dikondisikan oleh tengkulak, mereka umumnya tidak mendorong peningkatan kualitas produk, namun hanya mendorong kuantitas produk dan harganya menjadi murah, bahkan para tengkulak beberapa ada yang membeli gerabah dari perajin dalam bentuk gerabah yang masih mentah (belum dibakar). Hal ini tentunya perajin hanya mendapatkan keuntungan yang tidak banyak dan perajin memiliki keterbatasan dalam menginovasikan produknya. Sehingga upaya inovasi seringkali mengalami hambatan. Oleh karena itu, peneliti menjadi semakin yakin, bahwa ada sistem tata kelola produksi gerabah yang dilakukan perajin gerabah di Desa Pagelaran yang mempengaruhi hasil produksi dan juga akan berdampak pada perekonomian perajinnya (Saleh, 2020).

\section{Analisis dan Hasil}

Upaya yang dilakukan Sutrisno dalam membuat produk gerabah sudah melaju, kerja produktivitasnya tidak lagi sebagai alat produksi tradisional, namun sudah menggunakan teknologi dalam mengolah tanah liat, dan membentuk produk gerabahnya. Perkembangan terakhir, Sutrisno menggunakan mesin press untuk membuat keramik interior yang dipesan oleh konsumennya dari Bali. Bahkan juga membuat produk yang dikembangkan dari bentuk-bentuk belanga menjadi kap lampu. Upaya ini dilakukan dengan berbagai pertimbangan, yaitu (1) meningkatkan kemampuan teknik produksi tradisional,

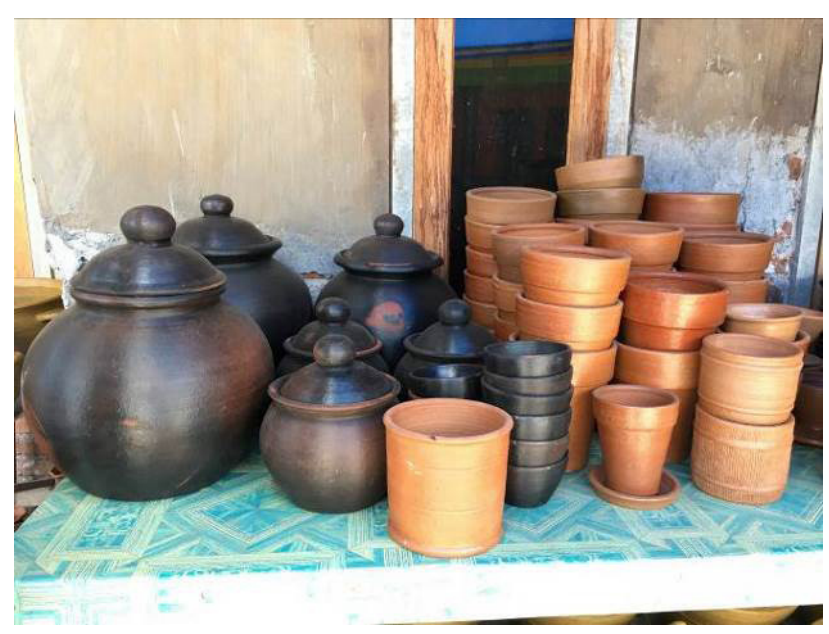

Gambar 5. Bentuk diversifikasi gerabah karya Sutrisno (Sumber: Foto Afaf, 2020)

(2) menggunakan teknologi untuk mengerjakan pekerjaan yang harus dilakukan dalam waktu yang lama dan dilakukan oleh banyak orang, (3) membidik pasar baru untuk membangun ruang bisnis yang lebih eksklusif. Jadi Sikap Sutrisno merupakan suatu cara untuk menumbuhkan kesadaran baru dalam menyikapi potensi tradisionalnya menjadi potensi yang lebih bersifat ekonomis. Selain itu mewakili sikap sosial masyarakat modern, yang mampu menerima berbagai alternatif untuk melakukan adaptasi sosial atau mengikuti keadaan (Sudirana, 2019). Hal ini sejalan dengan hasil penelitian terhadap perajin gerabah di Desa Kapal Kabupaten Ngawi (Widana et al., 2019), bahkan pemerintah mendukung sikap perajin yang bersedia mengambil langkah yang lebih bersifat ekonomis. Karena sistem kerja yang lebih praktis, dan memiliki prospek serta peluang pasar yang lebih luas adalah memberikan dukungan positif terhadap program industri kreatif (Azharman \& Susanti, 2020).

Fokus analisis yang digunakan pada penelitian ini adalah fungsional. Sebuah produk kebudayaan akan diberikan dukungan oleh penyangganya jika hal tesebut mampu menempati kebutuhan hidup manusia (Mahdayeni et al., 2019). Oleh karena itu, jika fungsi kebutuhan itu mengalami pergeseran, maka akan digantikan oleh kebutuhan yang lain, atau para penyangganya berusaha untuk melakukan transformasi, memodifikasi, dan atau mencari alternatif baru yang lebih inovatif. Pernyataan ini digunakan sebagai acuan, dalam melakukan analisis tata kelola produk gerabah di Pagelaran. Hasil yang dapat dikemukakan, terdapat 3 aspek yaitu, (1) diversifikasi produk gerabah, (2) meningkatkan kualitas produk, dan (3) dampak ekonomi.

\section{Diversifikasi Produk Gerabah}

Diversifikasi produk gerabah Pagelaran tumbuh bersifat individual, upaya yang paling menonjol adalah dilakukan oleh Sutrisno. Mengingat Sutrisno dapat digolongkan orang yang memiliki pengalaman di luar sentra gerabah 


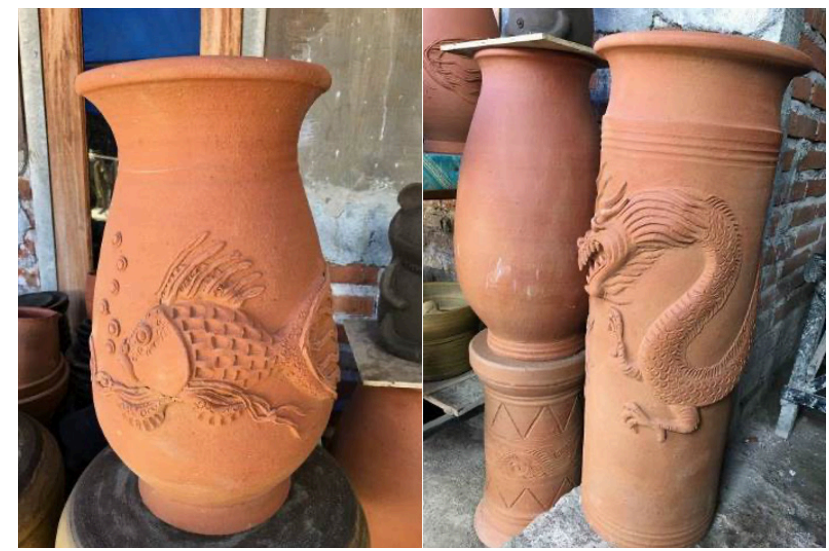

Gambar 6. Peningkatan kualitas produk gerabah dengan menambahkan ornamen pada benda pakai

(Sumber: Foto Afaf, 2020)

di desanya. Pergaulannya dengan para pedagang gerabah di Bali, sudah dilakukan dalam kurun waktu 5 tahun berselang. Hal ini yang membuka pikirannya untuk selalu memperhatikan perkembangan pasar wisata gerabah untuk interior hotel.

Diversifikasi produk yang dilakukan sebenarnya tidak terlalu jauh dari keterampilan produksi gerabah lokal, seperti teknik putar tegak atau miring. Sungguhpun teknik pembentukan gerabah tersebut memiliki fungsi yang berbeda, Sutrisno menyikapi teknik tersebut sebagai sarana untuk mengembangkan varian produk gerabah yang dihasilkan, baik membuat jenis belanga, atau membuat jenis pot bunga.

Gambar no. 5 menunjukan diversifikasi produk yang dikembangkan Sutrisno bertujuan untuk menumbuhkan minat konsumen pada gerabah tradisional, gerabah tersebut dilakukan dengan proses finishing yang sangat detail, sehingga bentuk tradisional dan mewah menyatu pada produk gerabah yang dihasilkan oleh Sutrisno.

\section{Meningkatkan kualitas Produk}

Segi tata kelola yang terkait dengan peningkatan kualitas pada umumnya juga dilakukan oleh semua perajin. Berbagai upaya kreatif dilakukan untuk memenuhi permintaan pasar, baik pasar domestik (lokal) atau pasar nasional atau internasional. Semuanya dilakukan lebih berorientasi pada aspek efisiensi, sehingga kualitas yang dimaksud adalah memenuhi kebutuhan pasar masingmasing (Yamirudin, 2019). Sutrisno berupaya secara kreatif untuk membidik pasar nasional dan internasional. Sehingga dari segi bentuk yang bersifat inovatif menjadi sasaran, baik diminta atau tidak diminta. Sehingga upaya kreatifnya dengan cara menciptakan pasar, memberikan penawaran alternatif pada para konsumen, dan konsumen tidak akan merasa jenuh pada produk lokal (Ranelis et al., 2019)
Sedangkan untuk perajin tradisional, usaha kreatifnya adalah memenuhi pesanan sebanyak-banyaknya dan mengerjakan secepat-cepatnya, sehingga tuntutan permintaan pasar lokal dapat dipenuhi dengan segera (Sunyoto \& Raharti, 2014). Hal ini juga mendorong para perajin menyiasati waktu, tenaga kerja, dan bahan baku yang dipandang lebih efisien. Hal ini seperti yang dilakukan oleh Sutrisno (gambar 6) meningkatkan kualitas produk dengan menambahkan ornamen untuk meningkatkan minat pasar pada produk lokal.

Gambar no. 6 menunjukan perubahan penampilan gerabah yang dilakukan oleh Sutrisno, kemauan untuk mengembangkan belajar untuk menginovasikan benda pakai menjadi daya minat konsumen untuk membeli produk gerabah.

\section{Dampak Ekonomi}

Tata kelola yang mengarah pada dampak ekonomi, kedua jenis perajin di Desa Pagelaran semuanya bersifat komersial. Namun strategi komersialnya yang berbeda. Satu sisi perajin yang berorientasi pada kuantitas yaitu memenuhi pesanan atas tuntuan pasar lokal bersifat kontinu. Dampak ekonominya diharapkan dapat menopang kehidupan sehari-hari (Priatin et al., 2017), sehingga mereka cara menghitung penghasilan adalah bersifat mengukur tenaga yang dikeluarkan. Sehari kerja diharapkan dapat menghasilkan pemasukan antara Rp. 100 -150 ribu/hari. Sungguhpun kondisi terakhir, mereka yang menekuni cara tradiosional tidak mampu mencapai penghasilan rata-rata tersebut. Kadang mereka hanya mampu menjangkau penghasilan antara Rp. 50-75 $\mathrm{ribu} / \mathrm{hari}$. Sementara untuk wanita dan anak-anak yang membantu kadang tidak mendapatkan penghargaan secara finansial, mereka dianggap sebagai penopang keluarga. Hal ini yang menjadikan, wanita dan anak-anak yang sudah remaja mencari pekerjaan lain di luar rumah, baik sebagai kuli bangunan atau buruh pabrik (M. A. Hasyimy, 2020).

Gambar no. 7 menunjukan perbedaan tata kelola yang dilakukan oleh Sutrisno, kemampuan untuk menggunakan tenologi mesin press guna meningkatkan hasil produksi, dan juga akan berdampak pada aspek ekonomi. Nurcahyani dan Septiana mengemukakan teknologi dapat memudahkan dalam memproduksi barang atau jasa, sehingga aktivitas produksi akan berdampak pada ekonomi (Nurcahyanti \& Septiana, 2018).

Tata kelola produksi gerabah yang dilakukan oleh Sutrisno, merupakan upaya menciptakan produk yang mempunyai dampak perluasan bisnis, sehingga penghargaan terhadap produk gerabah tidak lagi dihitung sebagai kuantitas, tapi barang selalu diposisikan dalam ukuran kualitas (Khoiriyah \& Sabardilah, 2020). Sehingga satu benda yang 


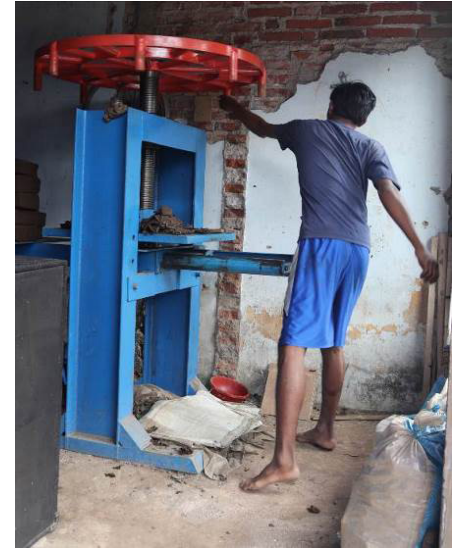

Gambar 7. Penggunaan alat teknologi press untuk produk tegel terakota

(Sumber: Foto Afaf, 2020)

dikerjakan mungkin dapat terjual antara Rp. 150-200 ribu. Sutrisno tidak hanya fokus pada gerabah rumah tangga, namun mulai mengerjakan pesanan untuk perlengkapan interior bersifat proyek, berupa tegel terakota. Bisa jadi pemesan untuk jenis tegel terakota dapat dipesan dalam ukuran kontrak pengerjaan antara 3-6 bulan. Sehingga setiap bulan dapat memasok produk keramik alternatif tersebut dapat ditargetkan mendapatkan omset antara 15 juta hingga 30 juta. Sungguhpun hal tersebut masih dalam kondisi perintisan, karena penghasilan dari kontrak tersebut juga dikurangi tenaga kerja dan juga perlatan berupa mesin press yang harus dibeli secara mengangsur.

\section{SIMPULAN}

Sentra produk gerabah di Desa Pagelaran Kabupaten Malang Jawa Timur yang menempati posisi sebagai sentra produk tradisional, fungsinya dalam menyangga kegiatan sosial dan ritual masyarakatnya. Seiring perkembangan zaman, tata kelola dalam memproduksi gerabah mengalami perkembangan. Ada dua pola yang saling tarik menarik, (1) tata kelola gerabah mengunakan pola lama, karena dapat lakukan tanpa menghadapi tantangan; baik permodalan atau pengadaan teknologi, (2) Tata kelola menggunakan baru sistem baru, dilakukan bagi perajin yang merasa ada perjuangan dan tantangan baru. Harus melakukan diversifikasi produk, meningkatkan kualitas produk, dan memiliki dampak ekonomi yang lebih baik.

\section{DAFTAR RUJUKAN}

Akbar, T., \& Prastawa, W. (2019). JADECS : journal of art, design, art education and culture studies. In JADECS (Vol. 3, Issue 2).

Azharman, Z., \& Susanti, E. (2020). Pembinaan Industri Kreatif Pada Jiwa Kewirausahaan Masyarakat. PUAN INDONESIA, 1(2), 65-70. https://doi.org/10.37296/about. v1i2.9
Betaubun, R. J., Latar, S., \& Maelissa, N. (2019). IBM MESIN PENGOLAH TANAH LEMPUNG UNTUK PEMBUATAN GERABAH. JURNAL PENGABDIAN MASYARAKAT IRON, 1(1). https://doi.org/10.31959/ JPMI.V1I1.272

Brata, I. B., \& Sudirga, I. K. (2019). Megeguritan: Media Pendidikan Karakter Generasi Muda Dalam Menghadapi Arus Budaya Global (Studi Kasus Di Desa Pakraman Bresela Payangan Gianyar). Mudra Jurnal Seni Budaya, 34(2), 230-238. https://doi.org/10.31091/mudra.v34i2.705

Darma Oka, I. M., Sudiarta, M., \& Widya Darmayanti, P. (2021). Warisan Cagar Budaya sebagai Ikon Desa Wisata Kaba-Kaba, Kabupaten Tabanan, Bali. Mudra Jurnal Seni Budaya, 36(2), 163-169. https://doi.org/10.31091/mudra. v36i2.1459

Gunada, I. W. A. (2021). Konsepsi Agama dan Seni Rupa dalam Rurub Kajang Tutuan (Kajian Estetika Hindu). Mudra Jurnal Seni Budaya, 36(2), 153-162. https://doi. org/10.31091/mudra.v36i2.1072

Hasyimy, M. 'Afaf. (2020). SENI SEBAGAI MEDIA TERAPI MELALUI PENGUATAN APRESIATIF DAN KREASI: STUDI KASUS PEMBELAJARAN SENI RUPA DI SMK NEGERI 7 MALANG. Unversitas Negeri Malang, 57.

Hasyimy, M. A. (2020). ESTETIKA GERABAH TRADISIONAL DI PAGELARAN: FUNGSI DAN SIMBOLISTIK. Prosiding Seminar Internasional Dancoc DKV UM.

I Wayan Mudra. (2019). GERABAH BALI. Media Sahabat Cendekia.

Iriaji. (2017). Identifikasi Karakteristik Visual, Teknik dan Makna Simbolik Kriya Gerabah di desa Pagelaran Kabupaten Malang sebagai Sumber Belajar Berbasis Kearifan Lokal. Fakultas Sastra Universitas Negeri Malang, Malang.

Iriaji. (2019a). ADAPTASI DAN SISTEM PENULARAN KRIYA GERABAH DESA PAGELARAN DALAM KONTEKS PERUBAHAN LINGKUNGAN SOSIOBUDAYA. In PROGRAM STUDI PENDIDIKAN SENI PASCASARJANA UNIVERSITAS NEGERI SEMARANG. UNIVERSITAS NEGERI SEMARANG.

Iriaji. (2019b). KARAKTERISTIK SOSIO-BUDAYA, PERGESERAN DAN POLA ADAPTASI KRIYA GERABAH PAGELARAN MALANG | Iriaji | Bahasa dan Seni: Jurnal Bahasa, Sastra, Seni, dan Pengajarannya. Bahasa Dan Seni: Jurnal Bahasa, Sastra, Seni Dan Pengajarannya, Volume 47(Nomor 1). http://journal2. um.ac.id/index.php/jbs/article/view/5435/pdf 
Iriaji, Rohendi R, T., Sumaryanto F, T., \& Sony K, D. (2020). The Tradition of Pottery Craftsmanship and Its Transmission System in Pagelaran Village, Malang Regency. KnE Social Sciences. https://doi.org/10.18502/ kss.v4i4.6475

Khoiriyah, N., \& Sabardilah, A. (2020). STRATEGI KEBERADAAN DI ERA MODERN DALAM MENINGKATKANNILAIJUALINDUTRIKERAJINAN GERABAH DI DESA KARUNGAN. Eklektik: Jurnal Pendidikan Ekonomi Dan Kewirausahaan, 3(1), 35-44. https://doi.org/10.24014/EKL.V3I1.10007

Koniherawati, K., \& Harjani, C. (2019). REAKTUALISASI KENDIL HITAM. Corak, 8(1), 13-16. https://doi.org/10.24821/corak.v8i1.2687

Mahdayeni, M., Alhaddad, M. R., \& Saleh, A. S. (2019). Manusia dan Kebudayaan (Manusia dan Sejarah Kebudayaan, Manusia dalam Keanekaragaman Budaya dan Peradaban, Manusia dan Sumber Penghidupan). Tadbir: Jurnal Manajemen Pendidikan Islam, 7(2), 154 165. https://doi.org/10.30603/TJMPI.V7I2.1125

Moleong, L. J. (2002). Metodologi Penelitian Kualitatif. Mujiyono, M., Haryanto, E., \& Gunadi, G. (2021). Peran Guru dalam Pengoptimalan Potensi Emosi Anak terhadap Peningkatan Kreativitas Ekspresi pada Pembelajaran Seni Rupa di SD Kota Semarang. Mudra Jurnal Seni Budaya, 36(2), 146-152. https://doi.org/10.31091/mudra. v36i2.1456

Nurcahyanti, D., \& Septiana, U. (2018). Handmade Eco Print as a Strategy to Preserve the Originality of Ria Miranda's Designs in the Digital Age. Mudra Jurnal Seni Budaya, 33(3), 395. https://doi.org/10.31091/mudra. v33i3.543

Ponimin, P., Widodo, T., \& Nusantari, O. A. (2019). PENGEMBANGAN DESAIN GERABAH TRADISIONAL SENTRA PAGELARAN MALANG DENGAN TEKNIK APLIKASI SERAT ALAM MELALUI PROGRAM KEMITRAAN MASYARAKAT. Imajinasi : Jurnal Seni, 13(2), 65-74. https://doi. org/10.15294/IMAJINASI.V13I2.21944

Prabowo, S. W., \& Rindawati. (2019). FAKTOR-FAKTOR YANG MEMPENGARUHI EKSISTENSI INDUSTRI GERABAH DI DESA RENDENG KECAMATAN MALO KABUPATEN BOJONEGORO. Swara Bhumi, 1(3). https://jurnalmahasiswa.unesa.ac.id/index.php/ swara-bhumi/article/view/28969

Prakoso, P. I. (2020). Peran Wanita dalam Industri Kerajinan Gerabah di Dusun Semampir, Bantul, Daerah Istimewa Yogyakarta. Jurnal Tata Kelola Seni, 6(2), 99113. https://doi.org/10.24821/jtks.v6i2.4773
Pratiwi, R. (2019). Sentra Kerajinan Gerabah di Malang. Jurnal Senirupa Warna, 7(1), 60-71. https://doi. org/10.36806/JSRW.V7I1.68

Pratiwi, R., Seni, K., Rupa, S., \& Kesenian Jakarta, I. (2019). Sentra Kerajinan Gerabah di Malang. Jurnal Senirupa Warna, 7(1), 60-71. https://doi.org/10.36806/ JSRW.V7I1.68

Priatin, Y., Surya, D., \& Suhendra, I. (2017). PENGARUH ORIENTASI PASAR DAN ORIENTASI KEWIRAUSAHAAN TERHADAP KINERJA PEMASARAN DENGAN INOVASI PRODUK SEBAGAI VARIABEL INTERVENING (Studi pada Kelompok Usaha Bersama (KUB) Gerabah di Desa Bumi Jaya Kecamatan Ciruas Kabupaten Serang ). Jurnal Riset Bisnis Dan Manajemen Tirtayasa, 1(1). https://doi. org/10.48181/JRBMT.V1I1.2609

Ranelis, R., Washinton, R., Malik, K., \& Trisnawati, D. (2019). Peningkatan Kualitas Sulam Koto Gadang Kabupaten Agam Sumatera Barat Melalui Pengembangan Desain Produk Dan Motif Untuk Mendukung Industri Kreatif. Mudra Jurnal Seni Budaya, 34(3), 349-357. https://doi.org/10.31091/MUDRA.V34I3.793

Saleh, A. (2020). PERUBAHAN SOSIAL BUDAYA MASYARAKAT PEDESAAN PASCA REVOLUSI HIJAU. In Jurnal Studi Ilmu Pengetahuan Sosial (Vol. 1, Issue 1).

Sudirana, I. W. (2019). Tradisi Versus Moderen: Diskursus Pemahaman Istilah Tradisi dan Moderen di Indonesia. Mudra Jurnal Seni Budaya, 34(1), 127-135. https://doi. org/10.31091/mudra.v34i1.647

Sunyoto, D., \& Raharti, R. (2014). KUALITAS STRATEGI BERSAING GUNA MENINGKATKAN KINERJA PERUSAHAAN PADA UKM DAN KOPERASI GERABAH KASONGAN BANTUL. EFEKTIF Jurnal Bisnis Dan Ekonomi, 5(2), 160-173.

Widana, I. K., Sumetri, N. W., \& Rasta, I. M. (2019). UPAYA PELESTARIAN GERABAH TRADISIONAL MELALUI IMPLEMENTASI MESIN GERABAH ERGONOMIS DI DESA KAPAL MENGWI. Bhakti Persada, 5(2), 1-13. https://doi.org/10.31940/bp.v5i2.1215

Yamirudin. (2019). PENGARUH INOVASI PRODUK DAN KUALITAS PRODUK TERHADAP KINERJA BISNIS DAN KEUNGGULAN BERSAING (STUDI PADA SENTRA UKM GERABAH DI KASONGAN BANTUL YOGYAKARTA). https://dspace.uii.ac.id/ handle/123456789/18312 


\section{Daftar Narasumber}

Sukirno (57 th) Perajin tradisional, wawancara tanggal 15 November 2020 di rumahnya, Dusun Getaan, Pagelaran, Kabupaten Malang.

Sutrisno (53 th) Perajin, wawancara tanggal 15 November 2020 di rumahnya, Dusun Getaan, Pagelaran, Kabupaten Malang.

Yatmono (57 th) Ketua Paguyuban Sentra Industri Gerabah Pagelaran, wawancara tanggal 2 Desember 2020 di rumahnya, Dusun Getaan, Pagelaran, Kabupaten Malang.

\section{UCAPAN TERIMAKASIH}

Peneliti mengucapkan terima kasih kepada dekan Fakultas Sastra Prof. Utami Widiati, M.A., Ph.D. Ketua Jurusan Seni dan Desain, Dr. Wida Rahayuningtyas, M.Pd. yang memberikan dukungan dan dorongan untuk menyelesaikan studi dalam waktu 3 semester. Demikian juga disampaikan ucapan terima kasih pada narasumber yang telah memberikan banyak informasi, keterangan, dan juga fasilitas observasi. Serta LP2M UM yang memberikan dukungan publikasi artikel ini sehingga dapat disebar luaskan pada masyarakat, khususnya bagi peneliti dan para seniman kriya di Indonesia. 